\title{
SOME GEOMORPHOLOGIC ASPECTS ALONG THE TIMIŞ RIVER IN THE ROMANIAN SECTOR
}

Marioara COSTEA *

* "Lucian Blaga" University, Faculty of Agricultural Sciences, Food Industry and Environmental Protection, 7-9 Raţiu Street, Sibiu, Romania, RO-550012, marioara_costea@yahoo.com

DOI: 10.2478/trser-2013-0030

KEYWORDS: floodplain, riverbed, transversal sections, fluvial processes.

\section{ABSTRACT}

This paper presents a geomorphologic analysis of the Timiş riverbed in Romania. The analysis was based on data from own observations in the field, within the project called "Protection measurements of Timiş River - Step II" Contract 411/90964/30.12.2010/07 by the University "Lucian Blaga" of Sibiu, Faculty of Sciences - Research Center of Applied Ecology, from June to December 2011.

Minor riverbed configuration and morphometry, the size of the material from the riverbed, and the forms of erosion and accumulation have been considered. This paper highlights the riverbed morphology in the different sectors (mountain, depression and plain), identifies the dominant fluvial processes and key features in the evolution of the Timis riverbed, and also establishes links between morphology, size of fluvial deposits and natural and anthropogenic control factors.

ZUSAMMENFASSUNG: geomorphologische Aspekte entlang des Timiş-Flusses im rumänischen Abschnitt.

Vorliegende Arbeit beinhaltet eine geomorphologische Analyse des Timiș-Flussbettes in Rumänien. Sie beruht auf eigenen Felduntersuchungen, die im Rahmen des Projektes "Schutz-Maßnahmen des Timiș-Flusses - Stufe II", Vertrag 411/90964/30.12.2010/07 an der "Lucian Blaga" Universität Sibiu/Hermannstadt - Forschungszentrum für Angewandt Ökologie, von Juni bis Dezember 2011 durchgeführt wurden.

Untersucht wurde Morphometrie und Konfiguration des Niedrigwasserbettes, die Korngröße des Bettmaterials sowie die durch Erosion und Anlandung entstandenen Bettstrukturen. Vorgestellt wird dabei die Morphologie des Flussbettes in verschiedenen Abschnitten, d.h. im montanen sowie dem Senkenbereich und den Tiefebenen. Hauptprozesse und Besonderheiten in der Entwicklung des Flussbettes wurden identifiziert und auch einige Beziehungen zwischen Morphologie, Größe der Ablagerungen und den natürlichen und anthropogenen Kontrollfaktoren festgelegt.

REZUMAT: Aspecte geomorfologice de-a lungul albiei Timişului, în sectorul românesc.

Lucrarea prezintă o analiză geomorfologică a albiei râului Timiş pe teritoriul României. Analiza s-a realizat pe baza datelor obţinute în urma observaţiilor de teren realizate în 2011, în cadrul proiectului „Măsuri de protecţie a râului Timiş - Etapa II” contract 411/ 90964/30.12.2010/07 realizat de Universitatea „Lucian Blaga” din Sibiu, Facultatea de Ştiinţe, în perioada iunie - decembrie 2011.

$\mathrm{Au}$ fost analizate configuraţia şi morfometria albiei minore, dimensiunea materialelor din albie, formele de eroziune şi cele de acumulare. În această lucrare este evidenţiată morfologia albiei pe diferite sectoare (montan, depresionar şi de câmpie), sunt identificate principalele procese fluviatile şi particularităţile în evoluţia albiei şi de asemenea s-au stabilit unele legături între morfologie, dimensiunea depozitelor şi factorii de control naturali sau antropici. 


\section{INTRODUCTION}

The Timiş River basin is part of the Banat hydrographic system and it drains an area of 7319 square kilometres, of which 5795 square kilometres are in Romania. The Timiş course exceeds the national border of Romania and flows into the Danube at Pančevo, downstream of Belgrade, in Serbia. The total length of the course is about $359 \mathrm{~km}$, from which 241.2 kilometres in Romania (Ujvari, 1972). The fluvial system is extremely complex due to its overlap over distinct relief units: mountains, depressions and hills, plains. The morphogenetic and morphometric features of transited relief units generate distinct geomorphologic characteristics of riverbed and morphodynamic differentiations (Fig. 1).

Between source (Semenic Mountains at 1,135 m altitude below Piatra Goznei Peak) and Armeniş the riverbed has a mountainous character. The course is carved into crystalline schists, presents an accentuated slope (average slope of $20 \mathrm{~m} / \mathrm{km}$ ) and the erosion processes prevail. Downstream Teregova, Timiş River enters into Timiş-Cerna Transcarpathian Corridor $(*, 1987)$, where the fluvial morphology is influenced by tectonics and by the contribution (liquid and solid flow) of Carpathian tributaries. In this sector, small depressionary areas alternate with gorges. In the Caransebeş Depression, developed on the sedimentary deposits of the Neogene basin, the Timiş riverbed has a meandered and divagated character (Linc, 2002).

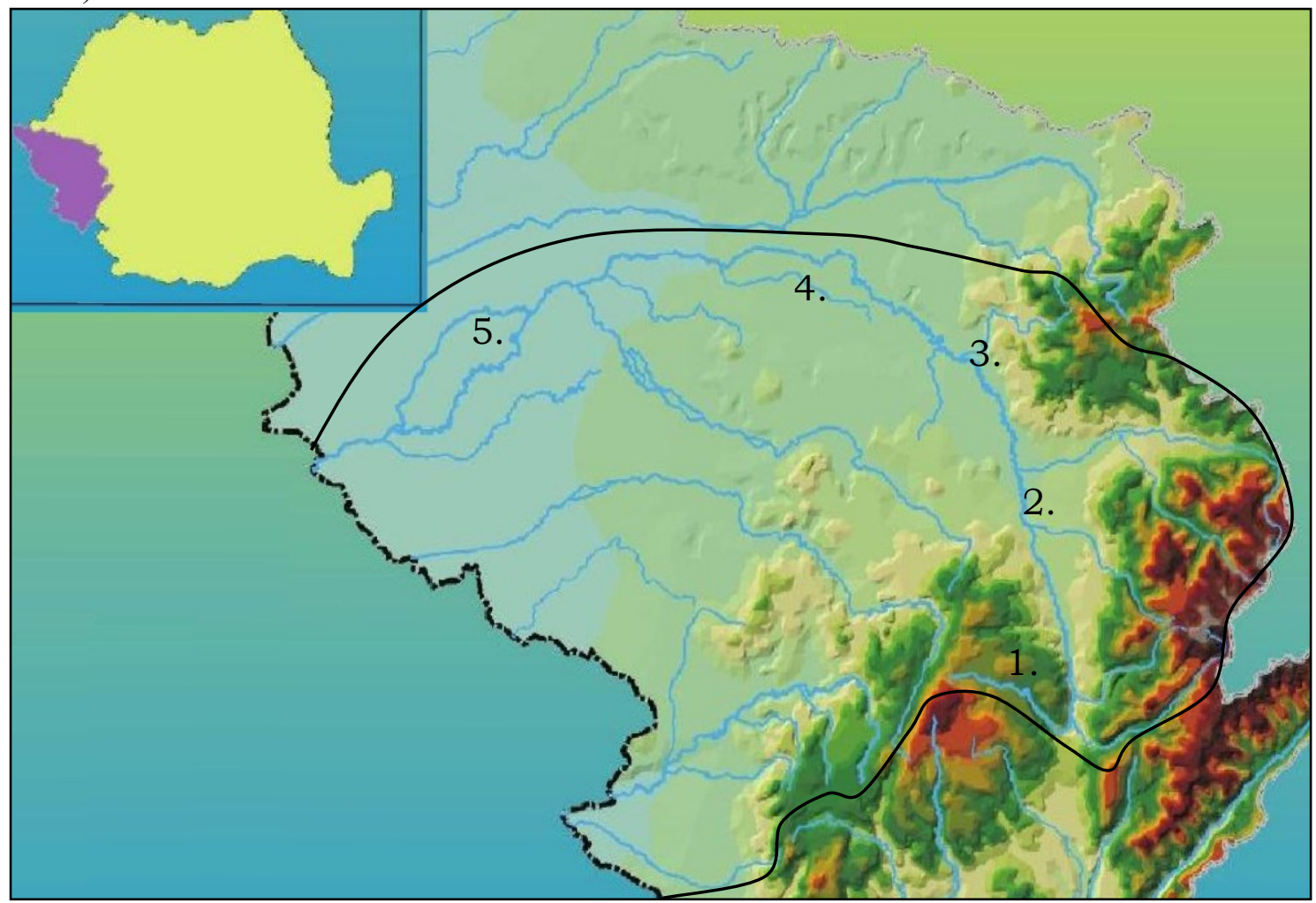

Figure 1: Timiş River basin in the Romanian territory and the relief units along the Timiş riverbed. Mountainous sector: 1. Semenic Mountains; 2. Caransebeş Depression; Hilly sector: 3. Lugoj Hills; Plain sector: 4. Lugoj Plain; 5. Timiş Plain. (http://www.directiaapelorbanat.ro) 
The morphometric characteristics of relief (very low slopes $0-7^{\circ}$, low relief energy 2 to $10-50 \mathrm{~m}$ ) determine the dominance of accumulation processes in the riverbed. In the piedmont plain of Lugoj, the Timiş Valley widens, the meandering processes and divagating character are increasing due to the decreasing slope (the average slope of the riverbed is about 1.6 $\mathrm{m} / \mathrm{km})$. In the Timiş Plain, the natural subsidence (1-2.5 mm/year) and the low slope (1-0.15 $\mathrm{m} / \mathrm{km}$ ) caused a great mobility of the riverbed (Ştef and Costea, 2006) by: disentangling, strong meandering, watercourse divagation, the presence of local depressionary areas with excess moisture. Agradation and riverbed elevation caused river flowing above the plain $(* *$, 1992). This character is maintained still nowadays, even though the river is embanked.

Throughout the entire course length, the dynamics of Timiş riverbed is subject to anthropogenic influence (Panţu, 2009) through direct intervention by crossing accumulation (Trei Ape dam), lateral reservoir, embankment, evacuation or additional off-flow through derivatives systems (Timiş-Bega), and by exploitation of materials (sand and gravel).

\section{METHODOLOGY}

The research methodology was based on field observations and on the geological, geomorphologic and hydrological data and procedures. The geomorphologic interpretations were derived from topographic maps (scale 1:100 000) and geologic maps (Harta geologică a României, 1968), direct measurements and cross section representation. Morpho-hydrographic analysis follows some significant issues: regional characteristics of geomorphologic features, data on petrography and superficial deposits, data on landform morphometry, especially on the floodplain (Lewin, 1978) and minor riverbed (Thorne, 1982; Schumm, 1985), fluvial forms and processes distribution (Leopold et al., 1964; Ichim et al., 1989). The field campaign was conducted on the entire length of the Timiş course. Representative sections were selected for observations and measurements (Fig. 2; Tab 1). Also, the analysis was based on minor riverbed transversal profiles (Figs. 3-8) obtained using graphics processing Mathcad (Sîrbu, 2009) of the collected morphometric data.

\section{ANALYSIS AND INTERPRETATION}

Section 1 is located on the upper sector of the Timiş River, in the Semenicului Mountains, downstream of the Trei Ape dam, at $802 \mathrm{~m}$ altitude. The mountainous relief is represented by Nergana leveling surface $(*, 1987)$, developed on the interfluves which surrounding the depression Gărâna - Brebu Nou, at altitudes of $1100-1050 \mathrm{~m}$. It is a polycyclic complex formed in the late Oligocene, located in extension of the upper complex (Semenic). The connection of this leveling surface with Gărâna - Brebu Nou Depression is done by inclined slopes $\left(45-60^{\circ}\right)$. Located around $\pm 200 \mathrm{~m}$ below this, there is an erosive depression dug into Holocene deposits. Timiş River has carved here a complex of five terraces (4-7 m, 10$15 \mathrm{~m}, 20-30 \mathrm{~m}, 35-50 \mathrm{~m}, 60-80 \mathrm{~m}$ ) and two levels of meadow. The horizontality of interfluves, the minor relief energy of medium leveling surface $\left(25-50-80-120 \mathrm{~m} / \mathrm{km}^{2}\right)$ and width of the depression, along with the favorability of climatic conditions have facilitated installation of the permanent settlements Gărâna and Brebu Nou.

Downstream of the depression, the Timiş River deepens in the lower leveling platform - Tomnacica (sculpted at the end of Miocene and early Pliocene). In this sector, there is a typical Carpathian Valley, carved in crystalline rocks of Timiş series, with relief energy of $200-250 \mathrm{~m}$ and a slope of 22 to $24 \mathrm{~m} / \mathrm{km}$. Downstream of the dam, the Timiş major riverbed is quite wide, with bilateral development, having two levels, the lower one at 0.5 to $1 \mathrm{~m}$ and a higher one at 1.5-3 m. The inferior level has a width of $4-6$ to $10 \mathrm{~m}$. The slopes are in direct contact with the major riverbed and have high declivity $\left(45^{\circ}-50^{\circ}-70^{\circ}\right)$. 


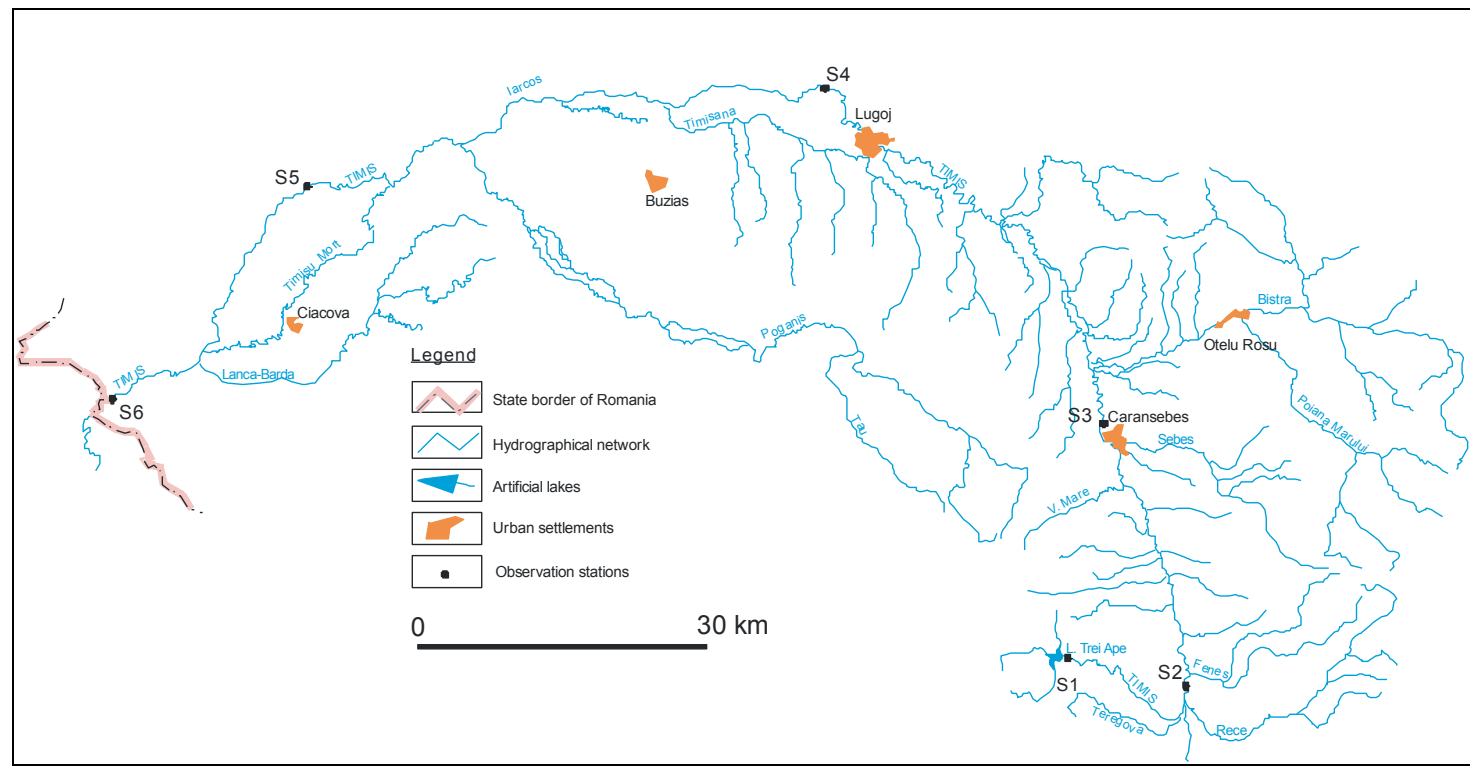

Figure 2: Transversal sections position along the Timiş River.

Table 1: Morphometry of Timiș riverbed; measured data.

\begin{tabular}{|l|l|c|c|c|c|}
\hline No. & \multicolumn{1}{|c|}{ Section } & $\begin{array}{c}\text { Altitude } \\
(\mathrm{m})\end{array}$ & $\begin{array}{c}\text { Channel } \\
\text { width B(m) }\end{array}$ & $\begin{array}{c}\text { Maximu } \\
\mathrm{m} \text { depth } \\
(\mathrm{m})\end{array}$ & $\begin{array}{c}\text { Average } \\
\text { depth } \mathrm{h}_{\mathrm{med}} \\
(\mathrm{m})\end{array}$ \\
\hline 1. & $\begin{array}{l}\text { Timiş downstream of Trei Ape } \\
\text { dam }\end{array}$ & 802 & 6.20 & 0.27 & 0.152 \\
\hline 2. & Timiş upstream Armeniş & 354 & 16.10 & 0.40 & 0.202 \\
\hline 3. & Timiş downstream of Caransebeş & 175 & 49.30 & 1.20 & 0.447 \\
\hline 4. & $\begin{array}{l}\text { Coştei Channel - Timiş-Bega } \\
\text { bypass }\end{array}$ & 116 & 26.0 & 2.32 & 1.291 \\
\hline 5. & Timiş at Şag & 83 & 49.5 & 1.60 & 0.518 \\
\hline 6. & Timiş at Grăniceri & 74 & 22 & 1.70 & 0.584 \\
\hline
\end{tabular}

The minor riverbed has a width of $6.2 \mathrm{~m}$ in the active section. The riverbed is made of hard rocks, metamorphic rocks belonging to the series of Timiş (gneiss, micaschists, amphibolites) with large size blocks $(5 \mathrm{~m} / 2 \mathrm{~m})$. Coarser $(1000 \mathrm{~mm} / 600 \mathrm{~mm}, 300 \mathrm{~mm} / 250 \mathrm{~mm}$, $400 \mathrm{~mm} / 250 \mathrm{~mm})$ and smaller boulders $(200 \mathrm{~mm} / 150 \mathrm{~mm}, 240 \mathrm{~mm} / 160 \mathrm{~mm})$ and gravel agglomerate the riverbed and form large islands and side accumulations. Accumulation of coarse material in the riverbed is caused by sudden reduction in this sector of the transport capacity of the river as a result of the fluid flow blocking behind the upstream dam (Ichim and Rădoane, 1986). Aggradation of the river channel by gravitationally intake from the slopes is also registered. The flow passed through the active section at the time of observation was about $0.108 \mathrm{~m}^{3} / \mathrm{s}$, the salubrious flow being assured through the bottom spillway. The riverbed depth is uneven, being minimum at river sides and maximum near the centre of the riverbed. The river average depth is about $0.152 \mathrm{~m}$ (Fig. 3). 
Section 2 is located at an altitude of $354 \mathrm{~m}$ in Teregova Gorges, $5 \mathrm{~km}$ downstream to Teregova, on the right side of the European road E 70. This sector is part of the Timiş - Cerna tectonic corridor. Upstream Teregova Gorges, along Timiş corridor develops a typical piedmont level - the Teregova level $(400-550 \mathrm{~m})$ that decreases in altitude from south to north according to the direction of the river flow, which has been shaped in RomanianVillafranchian sedimentary deposits. The landscape is complex. Teregova and Armeniş Gorges alternate with depressions. These two epigenetic gorges are carved into the Getic Nappe crystalline of the Timiş series and downstream of them the valley returns to the wide configuration of a depressionary corridor. Alternation of depressionary basins with gorges gives not only landscape diversity, but also a differentiated land use. Also, there are different conditions for the human settlements, these being located at the extremities of gorges in the small depressionary basins.

The valley is narrow and very sinuous. The slopes of the valley have accentuated slope $\left(60-70^{\circ}\right)$ and a different energy relief: $200-400 \mathrm{~m}$ on the left side and $80-100 \mathrm{~m}$ on the right side. The top of the interfluves on this side is part of the piedmont level with altitudes of 550$400 \mathrm{~m}$ and is covered by pastures and meadows, with small areas of orchards. On the left slope of the valley the high relief energy makes possible the direct connection of riverbed with lower levelled surface Tomnacica - Cârja $( \pm 800 \mathrm{~m})$. Both slopes and tops of the interfluves are well wooded with deciduous forests, thus limiting the action of gravity and pluvial denudation processes.

The riverbed has a width of $16 \mathrm{~m}$ in the active section, a maximum depth of $0.40 \mathrm{~m}$, an average depth of $0.20 \mathrm{~m}$ and a flow rate of $1.87 \mathrm{~m}^{2} / \mathrm{s}$ at the time of observation (Fig. 4). The bottom pavement (Ichim et al., 1989) is made of boulders $(500 \mathrm{~mm} / 400 \mathrm{~mm})$, coarser gravels and sands indicating a balance between fluvial processes. The active section has a right asymmetry, the maximum depth being reached at $2.5 \mathrm{~m}$ from this riverbank, which is higher, with accumulation of stones. The left bank is lower with accumulation processes of boulders, gravels and sands.

Section 3 is located downstream of Caransebeş, at $175 \mathrm{~m}$ altitude, upstream of the railway bridge. From a physico-geographical point of view, this section is located at the northern end of the Caransebeş Depression in a maximum wide sector which makes the transition to the Banat Plain. The Caransebeş Depression is built on sedimentary deposits of gravel, sandstone, limestone and sandy clays. In this geological substratum, the Timiş River has dug a wide valley in which we can identify the lower levels of the floodplain and terraces (4- $7 \mathrm{~m}, 10-15 \mathrm{~m}$ ). Floodplain of the Timiş River at Caransebeş has a width of $1.5-2 \mathrm{~km}$ and is suspended $2-3 \mathrm{~m}$ from the river channel. The transition to the first fluvial terrace is gradual, almost imperceptible, which gives the depression a lowland character. The riverbanks along Timiş are fixed by spontaneous forest vegetation, reeds and sedges and the floodplain is occupied by meadow and different crops, especially cereals. In the considered active sections, the river channel is asymmetrical, with depths up to $0.5 \mathrm{~m}$ over a distance of $35 \mathrm{~m}$ from the left bank, after which the depth suddenly increases up to $1.20 \mathrm{~m}$ (40 m above the left bank) (Fig. 5). The left bank is accumulated on a length of about $65 \mathrm{~m}$ with boulders, gravel and silt and is lower compared to the right bank which is higher $(2-3 \mathrm{~m})$ and eroded. In the river channel and at the left bank, coarser and medium size formations (boulders and gravel) predominate in proportion of $90 \%$, embedded in a sandy and muddy mass. The ccompetence of the river is quite high due to the accumulated flow on the upstream route. The reduced slope of the river favours the accumulation and unplaite processes and the formation of islands. 


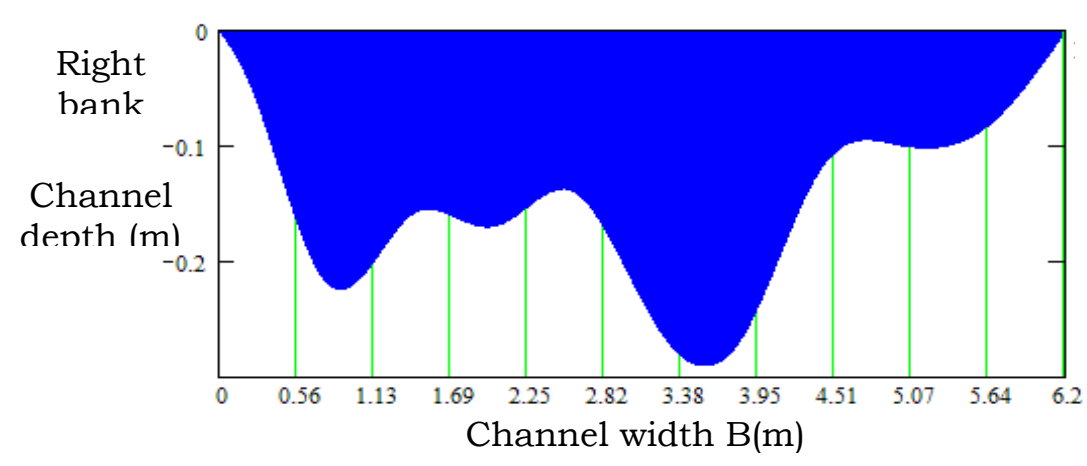

Left bank

Figure 3: Active section on Timiş River downstream Trei Ape

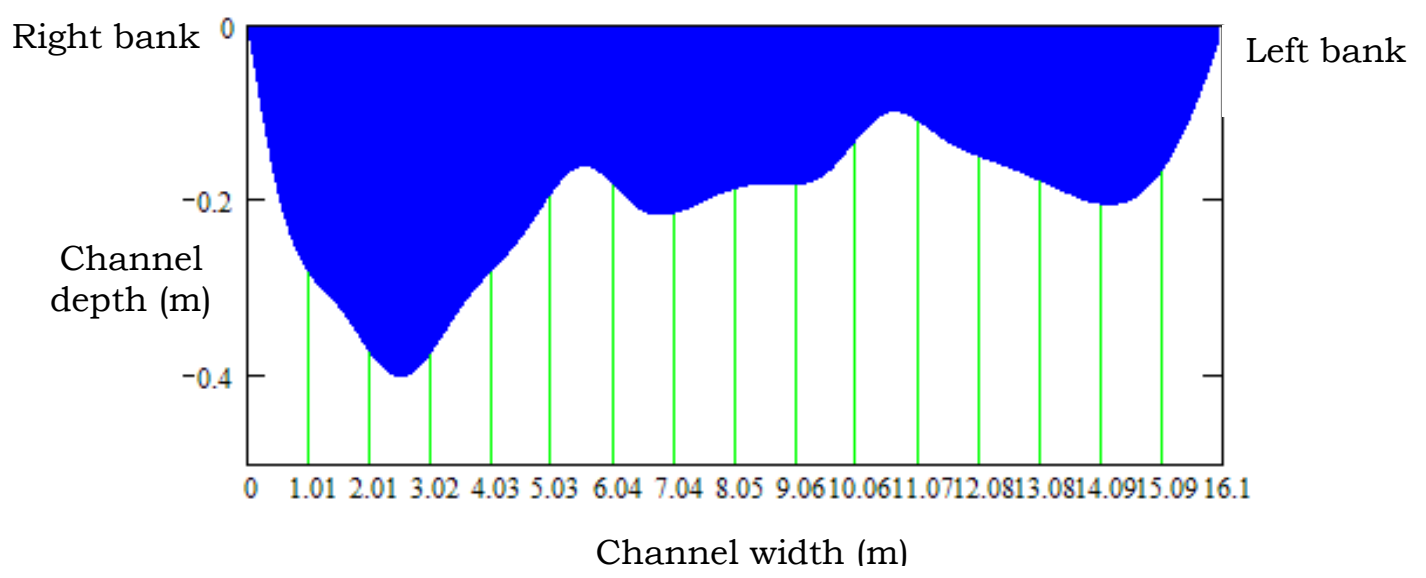

Figure 4: Active section on Timiş in Teregova Gorge.

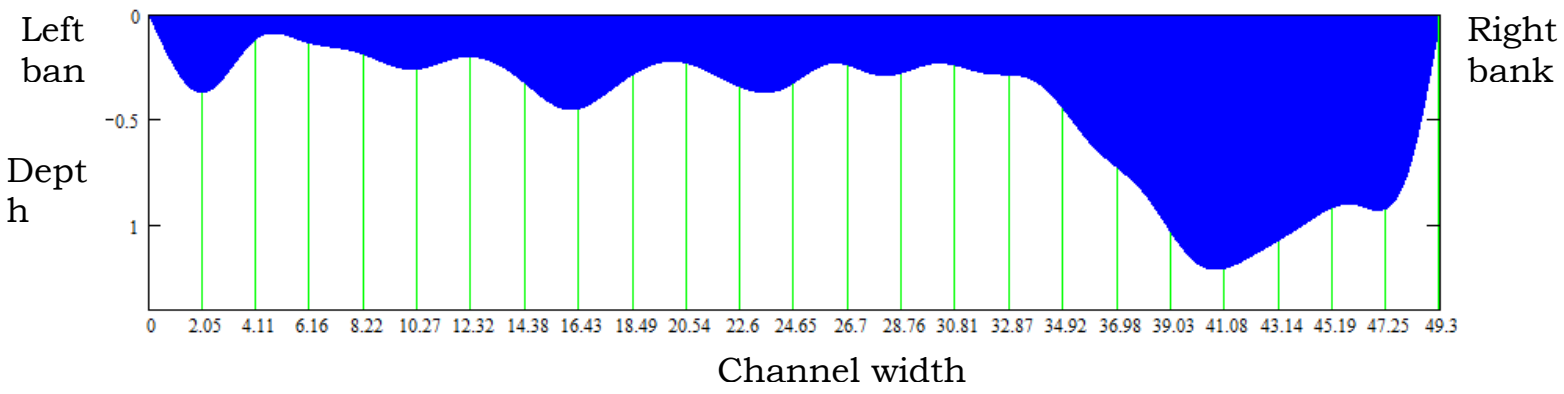

Figure 5: Active section on Timiş downstream Caransebeş.

The forms of accumulation and the banks are stabilized by vegetation: riverside coppice, adventives vegetation, reeds and sedges. At the time of observation the Timiss flowrate calculated by the section-velocity method was $15.46 \mathrm{~m}^{2} / \mathrm{s}$. Massive accumulations of gravel and boulders are exploited through the ballast pits at Caransebeş, as well as throughout Timiş. Export of material from riverbed changes the relationship between fluvial processes and deepens the minor riverbed to $3 \mathrm{~m}$ at least from the floodplain. Construction materials are exploited also from the floodplain, where the excavation depressions are fuelled from the river by groundwater and give rise to permanent ponds with specific vegetation. 
Section 4 is situated near the settlement Coştei, in Lugojului Plain, at an altitude of about $116 \mathrm{~m}$, in the hydrotechnical junction node Timiş - Bega. In this sector, the major riverbed of Timiş River is very large; the river has strong meanders, has formed many oxbows, abandoned meanders, disentangling and wetlands, especially upstream of Coşteiu. Following the work of land reclamation, Timiş was embanked and deepened and downstream Coştei the riverbed is dammed throughout its length in the plain. The dams have a height of 3 $5 \mathrm{~m}$ above the riverbed and protect the agricultural land of floodplain and settlements of flooding. In the alluvial plain, fluvial deposits consist of coarse sand and even gravel, on which occur alluvial soils in association with gley soils and eumezobazic wet soils. The granulometric composition is diverse and the horizons of soil profile are chaoticly stratified (cross structure).

Between the high banks of the Timiş River, protisoils are found - alluvisols developed on sand banks and on higher accumulations with coarser texture. The banks and islands are fixed or partially fixed by hygrophilous vegetation. Repeated fluvial processes, especially alluviation, lead to expansion and to formation of new alluvial layers between dikes. In the analysed section, the Timiş River channel has a width of about $110 \mathrm{~m}$ and is strongly modified as a result of human intervention. Through the bypass of Coştei (Panţu, 2009), a part of the flow is exported towards Bega. The Timiş River flow is deviated through minor riverbed changes towards the Coştei channel and through the existence of a transversal island and dam which are blocking the flow into Timiş. The flow rate directed toward Bega, calculated by the method of section - velocity, was $7.6 \mathrm{~m}^{2} / \mathrm{s}$ at the time of observation. (Fig. 6).

In this context, during the observation period, the Timiş riverbed was visibly affected by a drastic decrease of water level, by flow blocking and by interruption of connectivity with the river channel downstream of the dam. Behind the spillway dam, the waters are stagnant in quasi-lacustrine systems. The water level has decreased both because of flow removal through the Coştei channel and due to a severe drought recorded in the second half of 2011. The effects of this deviation and disruption of connectivity are emphasized downstream of the dam by the material exploitation from the riverbed. Excavations have led to the formation of isolated ponds and puddles that do not communicate with each other because of sand banks and artificial islands which block the leak. Under these conditions the riverbed geomorphology balance, but also the ecological, are deeply disturbed.

Section 5 is located in the Timiş Plain, at an altitude of $83 \mathrm{~m}$ to the south of Şag, upstream of the road bridge. Due to the lower altitude $(90-80 \mathrm{~m})$ than Lugojului Plain and due to the subsidence and divagation character of this plain, the Timiş course has meandered and has numerous bed mobility problems caused by active fluvial processes. The divagation character was slowed due to damming throughout the Timiş Plain, but the very small bed slope (from 0.15 to $0.45 \mathrm{~m} / \mathrm{km}$ ) still favours, between dikes, the meandering processes, strong and active processes of accumulation and the existence and continuous formation of sandy beaches. Stationary hydrologic processes occurred both between and beyond the dams lead to the formation of wetland areas, maintained by the direct contact with the river or groundwater which is near the surface. 


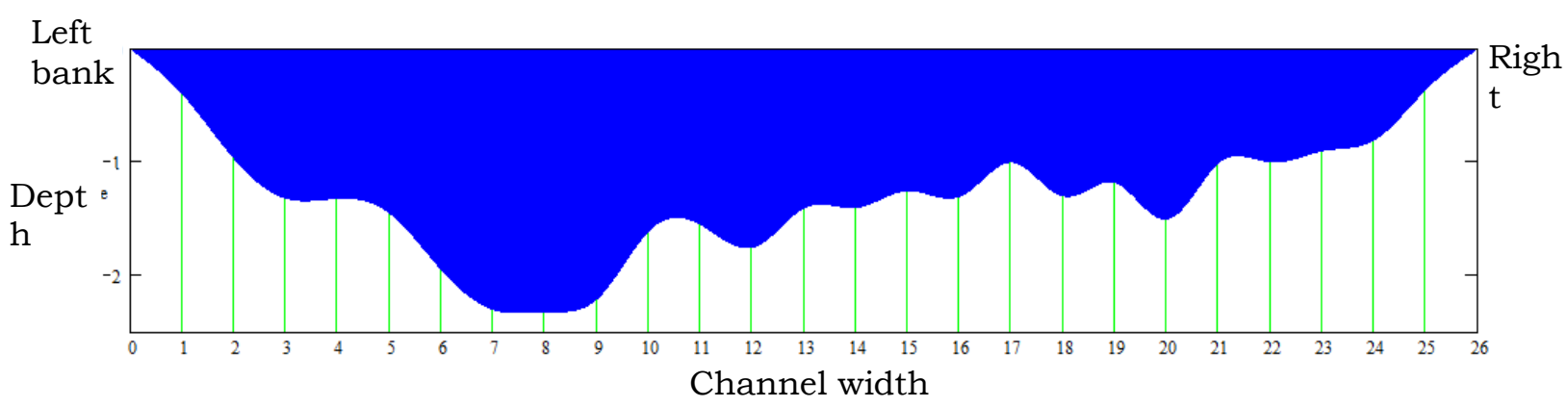

Figure 6: Active section on Coştei Channel - junction to Bega.

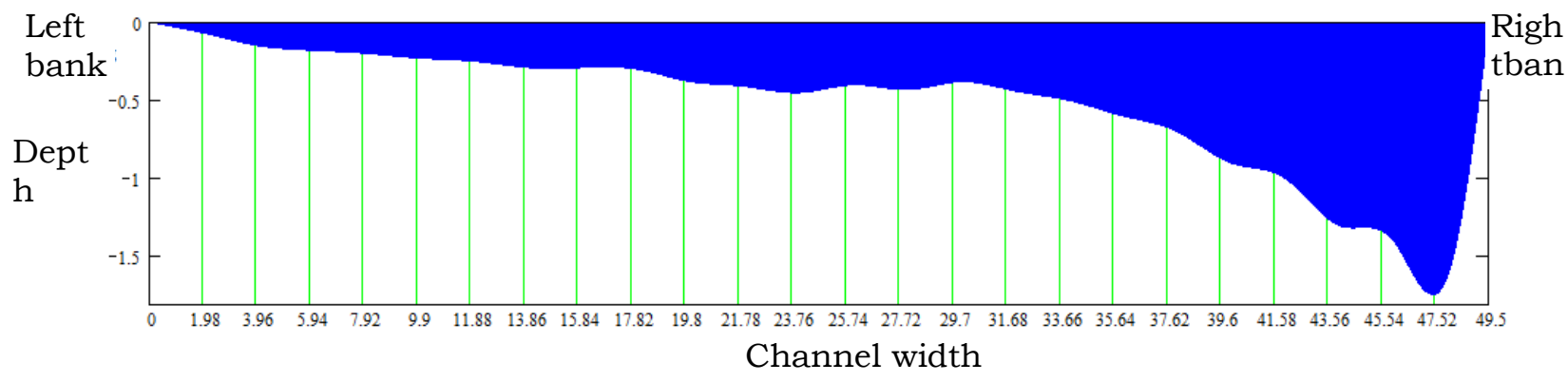

Figure 7: Active section on Timiş River to Şag.

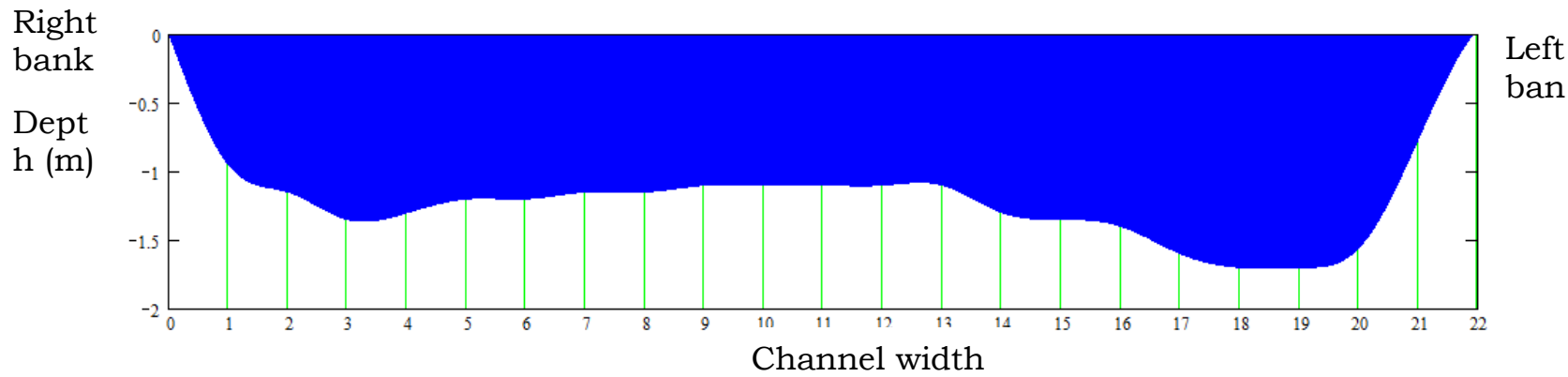

Figure 8: Active section on Timiş River to Grăniceri.

Direct observations were made in a meander loop (Fig. 7). The river is totally embanked. The right bank is high and eroded, and the left side is lower and accumulated. The sands are dominant (90\%) (micaceous sand, fine and silty sand) and silt (10\%) that were formed psamosoil and undeveloped soils (Ianoş et al., 1997). The terracing and embankment of the dam is done on three levels. Sands are fixed by willow riverside coppice forming a green corridor, interrupted here and there by grassy areas. Where the depositional processes are still active sands are not fixed. This sector of Timişului riverbed has also a leisure and recreation function for local people interested in fishing, walking or sunbathing.

Outside the dammed enclosures, on the newer alluvial deposits cambisoils are formed. Soil formation processes are increasing as a result of minor riverbed damming and reduction of the flooding risk in these areas (Ianoş et al., 1997). The land is used for agriculture, grain and forage being cultivated. 
Section 6 is located at $74 \mathrm{~m}$ altitude, about $1 \mathrm{~km}$ upstream from the RomanianSerbian border. Here the floodplain has the same characteristics as in the previous sector, belonging to the same unit of relief - the Timiş Plain: lack of terraces, flatness of the surfaces, meandering of riverbed. Altitudes are between 74 and $78 \mathrm{~m}$. Sedimentary geological substrata are composed of Quaternary deposits (sands, gravels), all covered by recent alluvial deposits.

The riverbed is embanked, and between dykes the soils (protisols) and alluvial deposits (recent fine silt) are subjected to the action of groundwater (near the surface $1-2 \mathrm{~m}$ ) and level fluctuations of Timiş River. The dykes system was rehabilitated after the floods from autumn 2006. These dams were built at a higher safety class to prevent flooding in this region and to reduce transboundary hydrological risks (Panţu, 2009). The dyke height from the water level at the time of observation was about $14 \mathrm{~m}$. The dikes are terraced and the riverside coppice which accompanied the Timiş course in this sector has been cleared to avoid the leakage blocking. The minor riverbed was also relatively levelled and the banks were consolidated to limit the erosion.

Due to the course meandering between dykes, an asymmetrical internal meadow has been formed. Upstream of the bridge, the riverbed is wider, with disentangling and active accumulation of islands and beaches. The riverbed is uniform downstream the bridge (Fig. 8), almost rectilinear, as a result of human intervention, and the internal meadow develops better on the right side (over $200 \mathrm{~m}$ wide). The dimension of fluvial forms and the continuous developing of them between the dykes indicate the entering of the riverbed into a new geomorphologic equilibrium phase after embankment.

\section{CONCLUSIONS}

The active fluvial processes and the flow contribute to the changing of the riverbed morphology. Erosion and accumulation are processes that succeed over time and in space along the river Timiş. Cross sections indicate a relative bed symmetry in the mountain and a strong asymmetry in the depression and plains. Changes in the riverbed by extension, narrowing, deepening or suspension are the result of flow regime and alternation of processes of erosion, transport and accumulation, all these being phases of the riverbed dynamics. The geological features, the morphometry of the riverbed and the flow remain the most important control factors, a correct management of the fluvial system being necessary. The monitoring of geomorphologic and hydrologic processes along the Timiş River is required even more, especially due to the already verified possibility of erosion of banks with destructive character and negative impact on the human habitat and economy (ex. 2006 floods).

The equilibrium adjustment and maintenance can be solved in an anthropic way, by a series of measures for the prevention and attenuation of the effects of erosion or accumulation processes and anthropogenic degradation. A comprehensive approach to all the factors involved in the riverbed dynamic and morpho-hydrographic imbalances induced by flow, gravel exploitation, calls for further interdisciplinary studies and their integration in the sustainable regional development desiderate.

\section{ACKNOWLEDGMENTS}

The author is grateful to "Study of the quality of Timiş water and registry of polluters source to border" (IV.1.2), a Phare CBS contract, no. 411 - 90964/30.12.2010/07 of "Lucian Blaga" University of Sibiu, Faculty of Sciences, financed by the European Community and to NGO Ecotur Sibiu for publishing of this paper. Also, the author thanks to the reviewers for suggestions and to all colleagues involved in the research, especially to Mr. Bănăduc D. and students Răchită R., Mărginean M. and Stoilă V. for the support in riverbed measurement in the field campaign. 


\section{REFERENCES}

1. Ianoş G., Puşcă I. and Goian M., 1997 - Solurile Banatului. Condiţii naturale şi fertilitate, Edit. Mirton, Timişoara, 392. (in Romanian)

2. Ichim I. and Rădoane M., 1986 - Efectele barajelor în dinamica reliefului, Edit. Academiei Române, Bucureşti, 157. (in Romanian)

3. Ichim I., Rădoane M., Bătucă D. and Duma D., 1989 - Morfologia şi dinamica albiilor de râuri, Edit. Tehnică Bucureşti, 404. (in Romanian)

4. Leopold L. B., Wolman M. G. and Miller J. P., 1964 - Fluvial Processes in Geomorphology, Freeman W. H., San Francisco, 522.

5. Lewin J., 1978 - Floodplain geomorphology. Progress in Physical Geography, 2, 3. Edit. Arnold, 408-437.

6. Linc R., 2002 - Culoarul Timiş - Cerna, Edit. Universităţii din Oradea.

7. Panţu H., 2009 - Modernizarea sistemului hidrotehnic Timiş-Bega, Edit. Politehnica, Timişoara, 241. (in Romanian)

8. Schumm A. S., 1985 - Patterns of alluvial rivers, Annual Review of Earth and Planetary Sciences, 13, 5-27.

9. Sîrbu I., 2009 - Bazele modelării proceselor şi sistemelor ecologice, Edit. Universităţii „Lucian Blaga" din Sibiu, 175. (in Romanian)

11. Ștef V. and Costea M., 2006 - Hidrologie aplicată, Edit. Universității „Lucian Blaga” din Sibiu, 297. (in Romanian)

12. Thorne C. R., 1982 - Processes and mechanisms of river bank erosion. Gravel-bed rivers, Hey R. D., Bathurst J. C. and Thorne C. R., (eds), John Wiley and Sons, Inc., Chichester, U. K., 227271.

13. Ujvari I., 1972 - Geografia apelor României, Edit. Științifică, București, 577. (in Romanian)

14. *, 1987 - Geografia României. Carpații și Depresiunea Transilvaniei, Edit. Academiei Române, București. (in Romanian)

15. **, 1992 - Geografia României. Regiunile pericarpatice, Edit. Academiei, București. (in Romanian)

16. ***, 1968 - Harta geologică a României. Foile Jimbolia, Timişoara, Deva, Scara 1:200000, Institutul Geologic al României. (in Romanian)

17. http://www.directiaapelorbanat.ro/ (in Romanian) 